\title{
STAY PUT AND THE INDIVIDUALS WITH DISABILITIES EDUCATION ACT: A PROPOSAL FOR CLARITY AND CHANGE
}

\author{
BLAKELY EVANTHIA SIMONEAU*
}

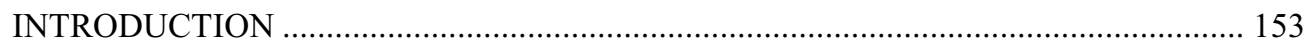

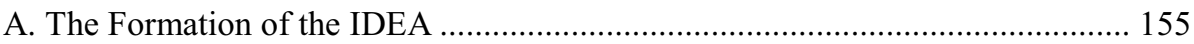

1. Mills v. Board of Education .................................................................. 157

2. Pennsylvania Association for Retarded Children v. Pennsylvania .............. 158

B. Mills, PARC, and the Beginning of the IDEA .................................................. 160

I. THE INDIVIDUALS WITH DISABILITIES EDUCATION ACT ................................ 162

A. Administrative Agencies and Disputes ........................................................... 163

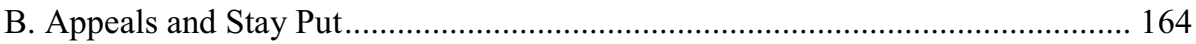

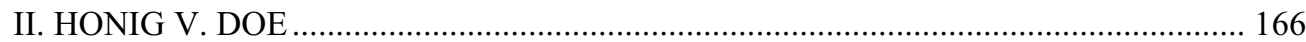

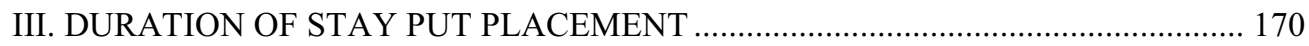

A. Circuit Court Split on the Duration of Stay Put Obligations .............................. 171

B. Educational Consequences of a Lengthy Stay Put Placement ........................... 173

C. Safety Consequences of a Lengthy Stay Put Placement ................................... 173

D. A Recommendation for a Shorter Period of Time ............................................... 175

IV. THE STAY PUT PROVISION AND PRIVATE SCHOOLS ...................................... 176

A. Arguments Against the Application of Stay Put to Private Schools .................. 178

B. Arguments in Favor of the Application of Stay Put to Private Schools ............. 181

C. Caselaw Offers No Clear Answer ........................................................................ 181

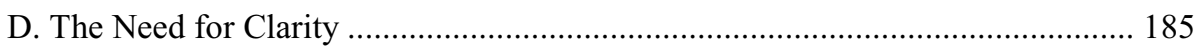

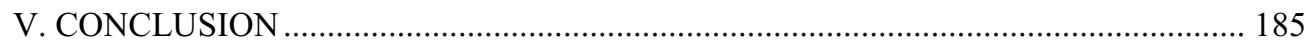

\section{INTRODUCTION}

As our understanding of disabilities and the specific needs of children with disabilities progresses, the educational landscape necessarily changes with it. With this comes a new class of parents, armed with internet searches and advanced advocacy skills for their children. So too are the schools changing. Public schools are now able to offer more student-specific approaches to students with disabilities, and private schools have become increasingly more specialized, catering to specific disorders and symptoms. But, with the transformation of special education services come new challenges.

The Individuals with Disabilities $\mathrm{Act}^{1}$, or the IDEA, was enacted forty-two years ago to

\footnotetext{
* Blakely Simoneau is currently employed at Success Academy Charter Schools. She was previously an associate at Clark, Hunt, Ahern \& Embry, where she worked in the Special Education Department.

1 Originally enacted as the Education for All Handicapped Children Act in 1975, it was renamed the Individuals with Disabilities Education Act in 1997. Although early case law refers to the Act by its former name, the substance of the Act is the same, and the change of name did not signal a change of purpose. For the purposes of this article,
} 
guarantee that all students, regardless of the nature or extent of their disabilities, receive a free public education. ${ }^{2}$ While the IDEA has by all accounts been successful in bringing services to students who were previously excluded from education services, it has failed to keep up with the changing landscape of special education. ${ }^{43}$ Further, despite three significant revisions, the IDEA has yet to resolve certain key issues that often undermine the very purpose of the Act.

Nowhere can this be seen more clearly than the currently unresolved issues surrounding the "stay put" provision. Two of these uncertainties in particular have created serious problems for schools, parents, and students. First, stay put orders are of indefinite duration, and often remain in place far too long. The effect has been to freeze the parties in inappropriate circumstances for drawn out periods of time while the matter wends through the current multi-stage resolution process. Second, the IDEA leaves uncertain whether private schools are even subject to stay put orders, a matter on which courts have come to opposite conclusions. This too has led parties to proceed with protracted litigation while the best interests of the student, the school, and the broader community are unprotected.

This article explores these problems and proposes two modest legislative remedies: clarification of the applicability of stay put orders to private schools, and limitation on the length of stay put placements during the dispute resolution process.

The centerpiece of the IDEA is the provision of a free, appropriate public education (often referred to as "FAPE") for all students regardless of their disabilities. The drafters of the IDEA anticipated that disputes would inevitably arise between parents and the schools in which their children were being educated. In an effort to preserve the status quo, and thus ensure the stability of the student and the provision of FAPE, the IDEA contains a provision commonly referred to as "stay put." ${ }^{4}$ This provision requires that, pending the resolution of any dispute, a student must remain in his or her current educational placement. ${ }^{5}$

Unfortunately, there is still much disagreement between the circuits as to many aspects of this provision. The uncertainty surrounding stay put has often resulted in just the kind of situations that the IDEA attempted to remedy, including children receiving inadequate educational services, children remaining in inappropriate placements, or even children being educated at home instead of in the classroom with their peers.

As our understanding of various disabilities progresses, so too does our understanding of the education services that each child with a disability may require. There will often be times when public schools lack the resources, staff, and specialization to provide a student with disabilities access to the services they require in order to receive a free, appropriate public education. The drafters of the IDEA were aware that these circumstances would arise and, therefore, built into the IDEA the ability of school districts to send these students to private, specialized schools at a rate

I will refer to the Act solely as the Individuals with Disabilities Education Act, or the IDEA. 20 U.S.C. $\S 1400$ et seq.

20 U.S.C. $\$ 1400(d)(1)(A)(2010)$.

3 "More than thirty years and several amendments later, the U.S. Department of Education reports that ' $[\mathrm{t}] \mathrm{he}$ majority of children with disabilities are now being educated in their neighborhood schools in regular classrooms with their non-disabled peers.' And '[h]igh school graduation rates and employment rates among youth with disabilities' have dramatically increased." Valerie Boland, Courts Misinterpret 'Stay Put' Provision of Individuals with Disabilities Education Act: Did Congress Really Intend to Take Services Away from Children with Disabilities?, 57 Drake L. Rev. 1007, 1008 (2009).

420 U.S.C. $\$ 1415(\mathrm{j})(2014)$.

5 Id. 
set by the government. An appropriate education for children with disabilities may now mean that the student must be sent to a private school specifically geared toward that student's disabilities. This framework offers clear benefits to students and is often an effective means for school districts to provide targeted education services to students requiring specialized services. Specialized private schools and ways of instruction have evolved over time to allow for more disability-specific education services.

As with public school placements, however, there are often disagreements among the private school, the parents, and the school district as to the appropriateness of the services provided. These can take the form of the school districts attempt to remove a publically funded private school student back into a public school, the parents disagreeing about the quality of education being provided in the private school, or, increasingly, the private school seeking to remove a student when they feel they are no longer able to provide the student with an appropriate education. Although a school may have been appropriate initially, students necessarily grow and the nature of their disabilities change. In circumstances where a school district, parents, or a private school disagree, parents often invoke stay put to maintain their child's placement in the private school pending the resolution of the dispute, just as they would were their child in a public school.

In these circumstances, important questions arise: does the IDEA's stay put provision bind private schools? Are private schools transformed into state actors, stepping into the shoes of the local education agency when they take these publically funded students? As with so many aspects of the IDEA, there is no clear answer. Further still, growing litigation on this issue has resulted in contradictory rulings.

By failing to evolve with the progress of special education services and provide the necessary guidance for interpreting the IDEA, Congress has created situations in which students are denied the right to a free, appropriate, public education merely by invoking the Act. This paper considers the circumstances leading up to the creation of the IDEA, with a particular emphasis on the genesis of the stay put provision. It explores the framework in which the stay put provision exists today. Furthermore, this paper looks at the still unresolved questions surrounding the stay put provision of the IDEA in relation to private schools, and how the uncertainty of this provision may ultimate harm the very students the Act was enacted to protect. Finally, this article demonstrates the urgent need for clarity in the IDEA, and the necessity for states to step up and enact their own legislation to protect students pending congressional action. ${ }^{6}$

\section{A. The Formation of the IDEA}

The Individuals with Disabilities Act ${ }^{7}$ was enacted in 1975 to "ensure that all children with disabilities have available to them a free appropriate public education. ... [and] ensure that the rights of children with disabilities and parents of such children are protected." ${ }^{8}$ The IDEA was enacted as a response to what had become a common and recurring problem: the exclusion of

6 States may enact regulations that supplement the IDEA; however, they may not offer less protection than that offered to students by the IDEA.

720 U.S.C. $§ 1400$ (d) (2014). The IDEA was initially called the Education for All Handicapped Children Act, but was later changed to the Individuals with Disabilities Education Act. Although early caselaw refers to the Act by its former name, the substance of the Act is substantially similar, and the change of name did not signal a change of purpose. For the purposes of this article, I will refer to the Act solely as the Individuals with Disabilities Education Act, or the IDEA.

820 U.S.C. $\$ 1400($ d)(1)(A)-(B); see also, Winkelman v. Parma City Sch. Dist., 550 U.S. 516,523 (2007). 
children with special needs from classrooms. This was often done by way of expulsion, suspension, or the recurring transfer of "problem" students to a series of different schools. ${ }^{9}$ Children with disabilities were frequently isolated from their peers as discipline for behavior resulting from manifestations of their disabilities. ${ }^{10}$ In fact, many children with disabilities were never identified as disabled and, therefore, never received services available to other disabled students.

Congressional hearings in 1975 revealed that millions of children with disabilities were still being shut out of American schools: 3.5 million children with disabilities in the country were not receiving an education appropriate to their needs, while almost one million more were receiving no education at all. By 1971-72, despite the fact that every school district in the United States had some kind of ongoing special education program, seven states were still educating fewer than $20 \%$ of their known children with disabilities, and 19 states, fewer than a third. Only 17 states had reached the halfway figure. ${ }^{11}$

At least one estimate held that only one out of every five students with disabilities were being publically educated before the IDEA. ${ }^{12}$ States responded to this problem by passing their own legislation to combat this problem. ${ }^{13}$ In fact, by the time the IDEA was enacted in 1975, at least forty-five states had enacted legislation concerning the education of children with disabilities. ${ }^{14}$ While these laws were in place to ensure at least some children with disabilities received education services, they were often ignored or, as a result of the lack of funding, compliance was not possible. ${ }^{15}$

Prior to the enactment of the IDEA, courts were often inundated with cases brought by students attempting to access education services. Two in particular received heightened attention. While Pennsylvania Association for Retarded Citizens v. Commonwealth of Pennsylvania and Mills v. Board of Education of the District of Columbia are often credited with leading to the formation of the IDEA, in reality, a series of cases and studies recognized the shortcomings of the special education systems. ${ }^{16}$ In fact, by 1973 , the principles articulated in these two cases had been upheld

$9 \quad$ "Through most of the history of public schools in America, services to children with disabilities were minimal and were provided at the discretion of local school districts. Until the mid-1970's, laws in most states allowed school districts to refuse to enroll any student they considered 'uneducable,' a term generally defined by local school administrators." Edwin Martin, Reed Martin, Donna Terman, The Legislative and Litigation History of Special Education, 6 The Future of Children, Spring 1996, no. 1, at p. 26.

10 This can be seen in several cases often credited with leading to the enactment of the IDEA. E.g., Pa. Ass'n for Retarded Children v. Pa., 334 F. Supp. 1257 (1971); Mills v. Bd. of Educ., 348 F. Supp. 866, 868 (1972).

11 Martin, supra note 9, at 29

12 Lauren Zykorie, Reauthorizing Discipline for the Disabled Student: Will Congress create a better balance in the Individuals with Disabilities Education Act (IDEA)?, 3 Conn. Pub. Int. L.J. 101, (2003) (citing Back to School on Civil Rights, NATiONAL COUNCIL ON DisaBILITY, (Jan. 25, 2000), http://www.ncd.gov/publications/2000/Jan252000 [https:// perma.cc/UC24-H8U8]).

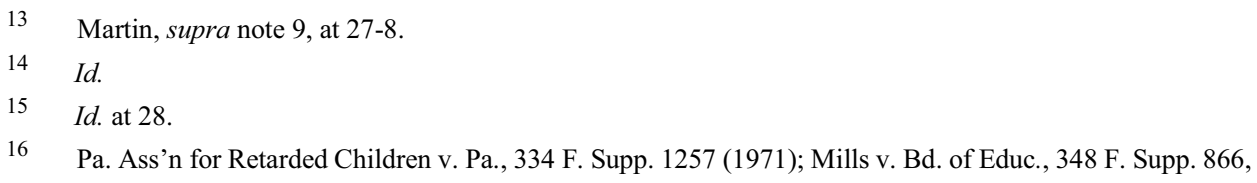
868 (1972). 
by over thirty federal court decisions. ${ }^{17}$

\section{Mills v. Board of Education}

Mills $v$. Board of Education was one of the first cases to challenge the laws preventing special education students from receiving education services alongside their peers. Mills involved the ongoing and systemic exclusion of students with disabilities from the District of Columbia public schools, through expulsions, suspensions, reassignments, and transferring of students requiring special education services. ${ }^{18}$ These students were not given full hearings or reviews. ${ }^{19}$ The class action lawsuit was brought on behalf of all children eligible for public education who had been excluded from public schools as a result of their disabilities. ${ }^{20}$ Plaintiffs in Mills brought their challenge under the Equal Protection and the Due Process clauses of the U.S. Constitution. ${ }^{21}$ Although D.C. laws at the time guaranteed students access to free public education, this guarantee was rarely fulfilled. ${ }^{22}$

The Mills court began by citing to a 1971 report from the District of Columbia public schools to the Department of Health, Education, and Welfare that estimated that over 12,000 students with disabilities were not educated during the 1971-1972 school year. ${ }^{23}$ Other children were systematically and repeatedly re-assigned to different schools when administrators thought they were too difficult, preventing these students from receiving consistent education services. ${ }^{24}$

The procedural history in Mills is particularly important in understanding the issues surrounding special education services at the time. The defendants, the Board of Education of the District of Columbia and its members, the Commissioner of the District of Columbia, the Superintendent of Schools for the District of Columbia, and the District of Columbia, routinely failed to comply with court orders. ${ }^{25}$ Although the parties entered into an interim stipulation meant to ensure compliance with state and federal law, the defendants failed to comply with the stipulation. ${ }^{26}$ The plaintiffs filed a motion requiring defendants to show cause as to why they should not be held in contempt, and a motion for summary judgment. ${ }^{27}$ The court scheduled a hearing and ordered the defendants to submit a copy of their proposed implementation plan. ${ }^{28}$ Yet, on the date

17 Martin, supra note 9, at 25, 28.

18 Mills v. Bd. of Educ., 348 F. Supp. 866, 868 (1972) ("The genesis of this case is found (1) in the failure of the District of Columbia to provide publicly supported education and training to plaintiffs and other 'exceptional' children, members of their class, and (2) the excluding, suspending, expelling, reassigning and transferring of 'exceptional' children from regular public school classes without affording them due process of law.”).

19 Id., at 872.

20 Id., at 868-69. ("The plaintiffs estimated that approximately 18,000 students who were eligible to receive services in the District of Columbia were being denied access.").

$\begin{array}{ll}21 & I d ., \text { at } 874-5 . \\ 22 & I d ., \text { at } 875-6 . \\ 23 & I d . \text { at } 868-9 . \\ 24 & I d . \text { at } 869 . \\ 25 & I d . \\ 26 & I d . \text { at } 872 . \\ 27 & I d . \\ 28 & I d .\end{array}$


of the hearing, the defendants failed to submit any implementation plan. ${ }^{29}$ Further frustrating the court, the defendants had continued to violate the stipulation and court's order by continuing to exclude disabled students from receiving education services. ${ }^{30}$

The court granted the plaintiff's motion for summary judgment, and ordered the defendants submit a proposed plan to the court within one year. ${ }^{31}$ The defendants, except one, failed to provide any proposed plan within the specified time. ${ }^{32}$ Although the Board of Education submitted a proposed order and plan to the court after the deadline, none of the other defendants endorsed or adopted the order. ${ }^{33}$ While the defendants acknowledged that they were under an obligation to provide a free education to the students, they claimed they lacked sufficient funds to comply. ${ }^{34}$

The court rejected the defendant's argument outright, focusing on the students' rights to educational services and the District's constitutional obligations. ${ }^{35}$ "The inadequacies of the District of Columbia Public School System whether occasioned by insufficient funding or administrative inefficiency, certainly cannot be permitted to bear more heavily on the 'exceptional' or handicapped child than on the normal child." 36

In finding for the plaintiffs, the Mills court concentrated not only on the District of Columbia's own laws requiring all students have access to education services, but also on the Due Process and Equal Protection Clauses. ${ }^{37}$ Citing to Brown v. Board of Education, the court noted that the right to access to education services must be applied on equal terms where the state has undertaken to provide it. ${ }^{38}$ The court went on to cite to later decisions implementing the Brown decision, finding "the doctrine of equal educational opportunity - the equal protection clause in its application to public school education - is in its full sweep a component of due process binding on the District under the due process clause of the Fifth Amendment." ${ }^{39}$ The Court continued: "[a] fortiori, the defendants' conduct here, denying plaintiffs and their class not just an equal publicly supported education but all publicly supported education while providing such education to other children, is violative of the Due Process Clause." 40

\section{Pennsylvania Association for Retarded Children v. Pennsylvania}

Pennsylvania Association for Retarded Children v. the Commonwealth of Pennsylvania, commonly referred to as "PARC," was brought the same year as Mills and arose out of similar circumstances. At the time of the suit, Pennsylvania law required that the state provide education to

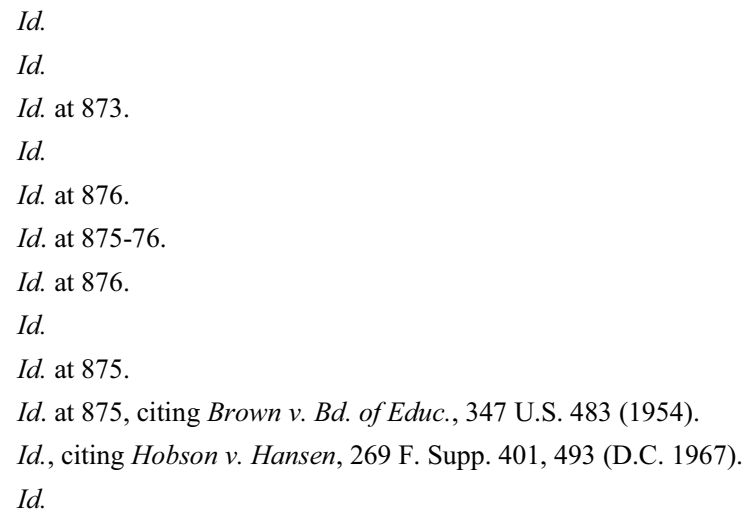


all children between the ages of six and twenty-one. ${ }^{41}$ This included children requiring special education services. ${ }^{42}$ Yet, those same laws permitted schools to exclude students who had not reached the mental age of five. ${ }^{43}$ Further, many schools were routinely denying services to students requiring special education services despite the state mandate by means of transferring, suspending, or expelling these students. ${ }^{44}$

$P A R C$ was a class action brought by students with disabilities against the Commonwealth of Pennsylvania. ${ }^{45}$ The students brought suit on behalf of all "mentally retarded persons, residents of the Commonwealth of Pennsylvania, who have been, are being, or may be denied access to a free public program of education and training while they are, or were, less than twenty-one years of age." 46 These students challenged not only the law, but also the schools' application of the law, alleging it was unconstitutional under the Equal Protection Clause. ${ }^{47}$ The parties ultimately agreed to a consent decree, which prevented the court from deciding the case on the constitutional issues. ${ }^{48}$ Nonetheless, the consent decree gave students with disabilities the right to education services they were otherwise being denied. ${ }^{49}$

As in Mills, the plaintiffs brought their suit under the Equal Protection Clause of the United States Constitution. ${ }^{50}$ In $P A R C$, the court noted that Pennsylvania had undertaken to provide a free, public education for all of its students, and therefore was barred from deny special needs students access to education services. ${ }^{51}$ The schools could not, therefore, categorically deny services to students who had not reached the mental age of five. ${ }^{52}$ The court conceded that special education students might have different capacities for learning than regular education students, but nonetheless required Pennsylvania to provide an education appropriate to that capacity:

Expert testimony in this action indicates that all mentally retarded persons are capable of benefiting from a program of education and training... It is the Commonwealth's obligation to place each mentally retarded child in a free, public program of education and training appropriate to the child's capacity ... ${ }^{53}$

41 Pa. Assoc. for Retarded Children v. Pa., 334 F. Supp. 1257, 1261 (1971), citing Section 1301 of the School Code of 1949, 24 Purd. Stat. Sec. 13-1301.

$42 \quad I d$.

43 Id. at 1260-63.

44 Pennsylvania's laws were by no means uncommon - several states had laws in place that mirrored Pennsylvania's. See Martin, supra note 9, at 25.

45 Pa. Assoc. for Retarded Children v. Pa., 334 F. Supp. 1257, 1260-63 (1971).

$46 \quad I d$. at 1258

47 Id. at 1259-60. The court cited to Brown v. Board of Education, 347 U.S. 483 (1954) in holding that the Equal Protection Clause applies to education and guarantees students have the right to educational opportunities.

$\begin{array}{ll}48 & I d . \text { at } 1258-9 . \\ 49 & I d . \\ 50 & I d . \\ 51 & I d . \\ 52 & I d . \\ 53 & I d .\end{array}$




\section{B. Mills, PARC, and the Beginning of the IDEA}

Both PARC and Mills recognized a gap in the accessibility of adequate education services for special education students, and emphasized the states' inability to remedy these situations. Equally important, these cases recognized a right to education services that becomes increasingly important in the creation and enforcement of the IDEA. They offer a clear picture of the issues surrounding special education services prior to the enactment of the IDEA. Not only were children routinely being denied access to adequate education, the law in some cases facilitated this treatment:

Through most of the history of public schools in America, services to children with disabilities were minimal and were provided at the discretion of local school districts. Until the mid-1970's, laws in most states allowed school districts to refuse to enroll any student they considered 'uneducable,' a term generally defined by local school administrators. ${ }^{54}$

Schools were able to either refuse enrollment completely, or to provide substantially subpar services to students. ${ }^{55}$ Both PARC and Mills involved groups of children with disabilities who were routinely receiving inadequate services and, at some point, were excluded from receiving educational services entirely.

A student who was expelled because of "disruptive behavior" that was simply a manifestation of their disability might remain out of school for weeks, if not months. ${ }^{56}$ Although any student might suffer academically if they were denied academic services for extended periods of time, a student with a disability might regress much more significantly if denied services, even for short periods of time. In fact, students with disabilities are more likely to be negatively affected by this exclusion, and can suffer long-lasting effects as a result.

Through these cases, one can begin to see the formation of many features of the IDEA. In fact, several key aspects of the IDEA, including the requirement that students receive notice and a chance for a hearing (due process rights), and the right to evaluations and re-evaluations to determine what services are necessary for each student (later encapsulated by the IEP team meeting requirements) can be found in these cases.

The ruling in Mills was pivotal and far-reaching. Children with disabilities had an equal right to public education offered in a form that was meaningful for them, and when the school considered a change in their status (including suspension, expulsion, reassignment, or transfers out of regular public school classes), the children were entitled to full procedural protections, including notice of proposed changes, access to school records, a right to be heard and to be represented by counsel at hearings to determine changes in individual programs, and regulatory scheduled status reviews. ${ }^{57}$

\footnotetext{
54 Martin, supra note 9, at 26.

$55 \quad$ Id. at 25.

$56 \quad$ See id. at 39 , footnote 37.

57 Martin, supra note 9 , at 28 .
} 
Important to this article, the $P A R C$ court acknowledged that school districts could place children in alternative (private) schools where they would receive special education services provided the school district pay for the student's tuition. ${ }^{58}$ This arrangement, whereby private schools accept publicly-funded special education students, is still a part of the IDEA today.

Also of importance to this article is the beginning of what would later be known as the "least restrictive environment" requirement, whereby students must be educated to the maximum extent possible among their peers. The $P A R C$ court noted that there is a presumption that "placement in a regular public school class is preferable to placement in a special public school class and placement in a special public school class is preferable to placement in any other type of program of education and training." 59 The Mills ruling similarly expressed a preference for this "Least Restrictive Environment." 60 This preference lives on in the IDEA, and continues to inform many aspects of the statute.

The stay put provision is based in part on this presumption - that students do best when educated with their peers, to the largest extent possible, and that schools should not be able to isolate students they find too difficult. Where public schools, like those in Pennsylvania and D.C., would routinely exclude special needs students from their peers through constant transferring, the stay put provision prevents the movement of the student so the parents can contest the transfer.

The PARC and Mills courts recognized that children with disabilities are uniquely susceptible to changes, and it is possible to watch a "backslide" effect when these children are denied these services. ${ }^{61}$ In fact, the Mills court expressly included a provision in its order that largely mirrors what would later become the stay put provision of the IDEA:

Pending the hearing and receipt of notification of the decision, there shall be no change in the child's educational placement unless the principal (responsible to the Superintendent) shall warrant that the continued presence of the child in his current program would endanger the physical well-being of himself or others. In such exceptional cases, the principal shall be responsible for insuring that the child receives some form of educational assistance and/or diagnostic examination during the interim period prior to the hearing.

This precluded public schools from routinely moving "problem" students without due process, and ensured that students receive consistent education services with their peers throughout any dispute.

These cases not only present a glimpse of the setting in which the IDEA was enacted, they also offer examples of why the stay put provision was a necessary piece of the IDEA. ${ }^{62}$ If the guarantees of the IDEA are to have any weight, students must not have gaps in education. Schools would often use the system to their advantage by repeatedly transferring, suspending, and expelling "difficult" students. This constant movement of students not only prevented them from receiving

\footnotetext{
58 Pennsylvania Ass'n, supra note 45, at 1263.

$59 \quad$ Id. at 1260.

60 Mills, supra note 10 , at 880.

61 See Pennsylvania Ass'n, supra note 45; Mills, supra note 10.

62 "During the 1960s and early 1970s, no state served all its children with disabilities." Martin, supra note 9 ,

at 27 .
} 
consistent educational services, but in some cases resulted in the complete cessation of any educational services. For example, if a student and their parents challenge the action of a school, the subsequent appeal process can often be lengthy and ultimately result in no change. ${ }^{63}$ During the resolution of these disputes, students were often denied access to any educational services, or are limited to inadequate education services. ${ }^{64}$ Simply by bringing suit, a student might be denied any education services they might have already been receiving or could have negotiated to receive from the schools.

Although its function and use has changed over time, the stay put provision was initially envisioned as a tool to prevent schools from engaging in the type of exclusionary practices that prevented students like those in PARC and Mills from accessing education services. Unfortunately, as this article will explore in more detail below, the provision today is often utilized to keep students in appropriate, sometimes unsafe, placements. The mere invocation of the provision can ultimately harm students in just the way the drafters of the IDEA attempted to prevent.

\section{THE INDIVIDUALS WITH DISABILITIES EDUCATION ACT}

The IDEA was enacted to remedy many of the ongoing and systemic issues related to the provision of special education services to students. The IDEA grants certain substantive and procedural rights to children age two through twenty-one, and mandates that each student must receive a free, appropriate public education ("FAPE"), a term of art defined by the statute as:

special education and related services that ... have been provided at public expense, under public supervision and direction, and without charge; . . meet the standards of the State educational agency; ... include an appropriate preschool, elementary school, or secondary school education in the State involved; and ... are provided in conformity with the individualized education program. . . ${ }^{65}$

Although defined by the statute, the term is one that is continually evolving over time as our knowledge of special education services, disabilities, and child development grows. In 201314 , the number of children and youth ages 3-21 receiving special education services was 6.5 million, or about 13 percent of all public school students. ${ }^{66}$

A brief overview of the key provisions of the IDEA helps inform the later analysis. Congress, recognizing that children thrive in educational environments where they are not isolated from their peers, mandated that children be educated with their peers in the "least restrictive environment" (commonly referred to as the "LRE"). ${ }^{67}$ Typically, the least restrictive environment is considered a regular education classroom. However, for some students the least restrictive environment may mean the use of a one-on-one (1:1) aide, attending a special education school, or, in some extreme cases, being educated in a residential special education school. Nonetheless, the preference for a student with disabilities to be placed in a regular education classroom is reflected

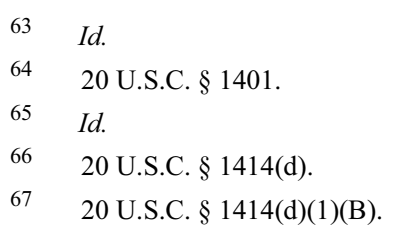


throughout the IDEA. Many of the issues surrounding placement of students with disabilities, and in particular with the discipline of these students and removal of dangerous or disruptive students from regular education classrooms, revolves around the requirement that schools attempt to educate special education students in the least restrictive environment.

In order to determine what services are necessary to serve a student with a disability, the IDEA calls for the creation of an individualized education plan ("IEP"). ${ }^{68}$ As is clear from the text of the IDEA, the creation of the IEP is intended to be an incredibly involved process, bringing together parents, educators, representatives of the local education agency, and occasionally the student (collectively referred to as the Individualized Education Program Team) ${ }^{60}$ It is also important to note that no IEP may be utilized if the parents do not consent to the provision of services outlined in the IEP.

Of particular importance for this article is the focus on the need to revise and revisit the IEP periodically. ${ }^{61}$ The drafters of the IDEA were well aware of the changing needs of students. As with any young child or teenager, the student necessarily grows and changes with time, sometimes dramatically over a short period of time. This may be even more true for special education students, especially in instances where a proper education program is developed to allow the student to progress significantly. ${ }^{69}$

\section{A. Administrative Agencies and Disputes}

For obvious reasons the IEP is one of the most important documents for students receiving special education services. The creation of the IEP, including the determination of what services are necessary for a student to receive FAPE, can often lead to heated discussions and disagreements among parents, schools, and school districts. In fact, disagreements are common. Typically, these disagreements revolve around what services are necessary for students to receive an appropriate education, the extent of those services, and the appropriateness of any placement or location. For instance, parties may disagree about whether the student must be educated in a special education classroom, or whether the student requires services the public school cannot provide and thus must be placed in private school (at public expense).

The drafters of the IDEA understood that situations like this would arise, and so mandated that any state receiving funding under the IDEA create an administrative agency to handle these disputes. Almost all claims must be brought before the administrative adjudicatory agencies, even if they involve other claims brought under other statutes and even if they seek remedies not available under the IDEA, such as punitive damages. ${ }^{70}$ In this way, the IDEA's reach is quite broad. These administrative agencies have the authority to hold hearings to resolve these disputes that can include the taking of evidence, examination of witnesses, and the consideration of motions. Understandably, hearings at the administrative level are often lengthy. ${ }^{71}$ If a party disagrees with the determination

\footnotetext{
68 IEPs must be reviewed and revised every year.

69 For example, a student who once required the use of a one on one (1:1) aide may be able to function, within a short period of time, without the use of aids at all with proper education.

70 Individuals with Disabilities Education Act, 20 U.S.C. $\S \S 1415(\mathrm{~b}), 1415(\mathrm{e}), 1415(\mathrm{f}), 1415(\mathrm{i})$ (2006).

71 In fact, once a parent files a complaint with an administrative agency there is a thirty day waiting period for the hearing to actually take place, intended to give the school and the parents time to convene and resolve the dispute. It is only once the thirty days are up, and the parents still allege the issue cannot be resolved outside of the administrative agency, that the hearing actually takes place (with limited exceptions). 34 CFR $\S 300.510$ (b).
} 
of a hearing officer, parties may appeal the administrative decision to a federal or state court but only after they have exhausted their administrative remedies, with limited exceptions. ${ }^{72}$

Regardless of the best intentions of any parties, the disputes over a child's special education services can last months or even, in some cases, years. To begin with, as with many hearings or trials, it may be months before a hearing date is available and scheduled. ${ }^{73}$ Other factors further complicate and prolong the process, such as the requirement that a student undergo academic or psychological evaluations prior to any determination by a hearing officer. This right to appeal often further extends the amount of time it can take to resolve the dispute.

With this framework in place, there was a valid concern that children would be without education services during the course of these disputes. As detailed in the prior section, before the enactment of the IDEA, students were often denied services when they attempted to assert their right to those very services. ${ }^{74}$

With these scenarios in mind, Congress drafted the "stay put" provision of the IDEA. Stay put refers to the student's right to remain in their "then-current educational placement" during the course of a dispute under the IDEA:

[D]uring the pendency of any proceedings conducted pursuant to this section, unless the State or local educational agency and the parents otherwise agree, the child shall remain in the then-current educational placement of the child, or, if applying for initial admission to a public school, shall, with the consent of the parents, be placed in the public school program until all such proceedings have been completed. ${ }^{75}$

Stay put acts as an automatic injunction. Merely by invoking stay put, the parents invoke their right to keep the child in their current educational placement. Stay put was designed to be farreaching. For instance, even if a student was not receiving special education services at the time the dispute arose, a student may claim stay put protection if the school was aware or reasonably should have been aware of the disability. ${ }^{76}$

\section{B. Appeals and Stay Put}

As mentioned previously, parties may appeal decisions from the administrative agencies to state or federal court. ${ }^{77}$ These cases then proceed like any other case, with appeals continuing up

7220 U.S.C. $\S 1415(\mathrm{i})(2)$ ("Any party aggrieved by the findings and decision . . . shall have the right to

bring a civil action with respect to the complaint presented pursuant to this section, which action may be brought in any State court of competent jurisdiction or in a district court of the United States, without regard to the amount in controversy."). See also, e.g., Rose v. Yeaw, 214 F.3d 206, 211 (1st Cir. 2000) (recognizing an exception to the exhaustion requirement in the case of futility or "severe harm" to the litigant).

73 In limited circumstances, parents or the school district may request an expedited hearing.

74 See Board of Education of the Hendrick Hudson Central School District Bd. of Ed., et al., v. Amy Rowley, by her parents and natural guardians, Clifford and Nancy Rowley, 458 U.S. 176 (1982). See also Mills, supra note 10.

7520 U.S.C. $\S 1415(\mathrm{j})$.

7620 U.S.C. $\$ 1415(\mathrm{j})-(\mathrm{k})$.

77 Parents may bring a complaint for an impartial due process hearing before a local education agency or state education agency (depending on state law). If the local education agency conducts the hearing, the party may appeal to the 
and until reaching the United States Supreme Court. ${ }^{78}$ Complicating this scheme, however, is the fact that parents and educators have the right to litigate nearly every aspect of the administrative hearing. ${ }^{79}$ "Virtually every decision made by school officials is subject to review, and by the time the required review process is completed, a student may have graduated . . " 80 Not surprisingly, the resolution of these issues often take time. "The IDEA and its implementing regulations do not specify a specific timeframe or specific process for identifying a school district's agreement or disagreement regarding what constitutes the current educational placement."

Student discipline plays into this, although the statutory scheme around student discipline has changed over the years and is slightly different than for other hearings. Students with disabilities who violate a school's code of conduct may be suspended up to ten cumulative days in one year. ${ }^{82}$ After this, if a student violates the code of conduct and the disciplinary result would be suspension, the school must conduct what is called a "manifestation determination review" (commonly called an "MDR"). ${ }^{83}$ If the student's conduct is not a manifestation of their disability, they may be disciplined as any other child would ${ }^{84}$ If their conduct is found to be a manifestation of their disability, they must be returned to their last placement and cannot be removed from the school to serve a suspension or other disciplinary punishment. ${ }^{85} \mathrm{In}$ this case, parents may request an expedited hearing if they do not agree with the school's determination. ${ }^{86}$

Further, a school district or parent may contest the placement of a student, including a stay put placement, to a hearing officer if "maintaining the current placement of the child is substantially likely to result in injury to the child or to others. . ." ${ }^{87}$ The burden is on the school to prove this. ${ }^{88}$ It is entirely within the discretion of the hearing officer to determine whether there is in fact a safety risk. The hearing officer then has the ability to order a change in placement for up to forty-five

state educational agency. A non-prevailing party then has the right to bring a civil action in state or federal court 20 U.S.C. $\S 1415(\mathrm{i})(2)(\mathrm{A}) ; 20$ U.S.C. $\S 1415(\mathrm{~b})-(\mathrm{g}) ; 34$ C.F.R. $\S \S 300.514(\mathrm{~b}), 300.516$.

$78 \quad I d$.

79 See 20 U.S.C. $\S 1415(\mathrm{j})-(\mathrm{k})$.

80 Kelly S Thompson, Limits on the Ability to Discipline Disabled School Children: Do the 1997 Amendments to the IDEA Go Far Enough, Indiana Law Review, Vol. 32:565, 581 (1999).

81 Office of Special Education, Dept. of Education, Letter to Stephen Goldstein (October 18, 2012).

$82 \quad 20$ U.S.C. $\S 1415(\mathrm{k})(1)(\mathrm{B})-(\mathrm{G})$.

$83 \quad I d$.

84 However, if the disciplinary consequence is removal from the school these students must receive education services in what is called an Interim Alternative Education Setting ("IAES"). Whether a student's conduct was a manifestation of their disability has far-reaching consequences for students. If the behavior is determined to not be a manifestation of the student's disability, for instance if a student with a learning disorder was caught cheating on a test, the student may be disciplined in the same way as a regular education student. 20 U.S.C. $\S 1415(\mathrm{k})(1)(\mathrm{C})$. For the purposes of this article, the many intricacies of the manifestation determination review and the IAES placements are not explored in more depth.

85 If the behavior was a manifestation of the student's disability, the IEP team must conduct or review a functional behavior assessment and behavior intervention plan.

86 An expedited due process hearing must occur within twenty days, and the hearing officer must render a decision in ten. 20 U.S.C. $\$ 1415(\mathrm{k})(3)(\mathrm{A})$; 34 CFR $\S 300.532(\mathrm{c})(2)$.

$\begin{array}{ll}87 & 20 \text { U.S.C. } \S 1415(\mathrm{k})(3)(\mathrm{A}) . \\ 88 & 20 \text { U.S.C. } \S 1415(\mathrm{k})(3)(\mathrm{A}) .\end{array}$ 
days. ${ }^{89}$ Yet, even if the hearing officer determines that there is a health or safety risk, the change in placement can only last up to forty-five days. After the forty-five days have lapsed, the student must then return to their last placement. Further, as with any decision by a hearing officer, the decision may be appealed.

There are other very limited "special circumstances," under which a student may be removed for up to forty-five days. These occur when a student:

(i) carries or possesses a weapon to or at school, on school premises, or to or at a school function under the jurisdiction of a State or local educational agency;

(ii) knowingly possesses or uses illegal drugs, or sells or solicits the sale of a controlled substance, while at school, on school premises, or at a school function under the jurisdiction of a State or local educational agency; or

(iii) has inflicted serious bodily injury upon another person while at school, on school premises, or at a school function under the jurisdiction of a State or local educational agency. ${ }^{90}$ Even under these circumstances, a student cannot be removed past the forty-five day mark.

Litigation is often nowhere near complete at the ten (or even forty-five) day mark. In that case, the student is returned to their educational placement, regardless of the appropriateness of the services or the safety of the school's staff and students. Even after the dispute over the discipline is over, parents and schools may still contest the placement or services of the student. The student's stay put placement is still that school.

Initially, the state agencies may have been able to quickly resolve disputes, however today they are often bogged down with long backlogs of cases. More and more students are receiving special education services, meaning these agencies get increasingly more complaints. Furthermore, the complaints may involve more complex issues due to the fact that our understanding of mental illness and disabilities has necessarily increased over time. ${ }^{91}$

In short, the litigation of a special education dispute can take significant periods of time, during which time the student remains in his last agreed-upon educational placement. Under the framework provided by the IDEA, students invoking stay put may be at the whim of an overcrowded system, bogged down by the well-intentioned, but nonetheless slow, resolution process.

\section{HONIG V. DOE}

By far the most significant case addressing the stay put provision is Honig v. Doe, decided thirteen years after the enactment of the IDEA. ${ }^{92}$ This case went before the United States Supreme

89 Id

9020 U.S.C. $\S 1415(\mathrm{k})(1)(\mathrm{G})$.

91 Although the IDEA requires written decisions be rendered within forty-five days of the expiration of the thirty day waiting period (prior to filing a complaint but before the hearing), so a total of 75 days from the filing of the complaint, it is not uncommon for hearing officers to exceed this time.

92 See Honig v. Doe, 484 US 305 (1988). 
Court to determine whether there was a "dangerousness exception" to the stay put requirement, allowing schools to expel special education students when their conduct created a safety risk to themselves or others. ${ }^{93}$

Under the plain language of the IDEA at that time, a student had a right to stay put in his then-current educational placement if his conduct, however dangerous, is a manifestation of his disability. ${ }^{94}$ Any suspension longer than ten days was considered a change in placement and a violation of the IDEA. ${ }^{95}$ Schools nonetheless were suspending, and in some cases expelling, students whose disability-related conduct was perceived as creating a risk of harm to themselves or others. ${ }^{96}$ These schools reasoned that the IDEA could not have been drafted to create situations in which dangerous students, regardless of their disabilities, were placed in classrooms creating a risk to the safety of other students or even themselves.

Honig concerned two students described as emotionally disturbed who were receiving special education services pursuant to the IDEA in the San Francisco Unified School District. ${ }^{97}$ The first student, identified under the pseudonym John Doe, was described as socially and physically awkward, with impulse control and anger issues. ${ }^{98}$ This was further exacerbated by what was described by the court as physical abnormalities, speech problems, and issues with hygiene, symptoms that left Doe alienated from and often taunted by his peers. ${ }^{99}$ Doe was described as becoming easily frustrated and "explosive" in response to these taunts. ${ }^{100}$ On November 6,1980 , Doe was taunted by one student and responded by choking the student hard enough to leave abrasions on the student's neck. ${ }^{101}$ When school officials attempted to remove Doe from the student, Doe responded by kicking out a school window. ${ }^{102}$ As a result of this incident, the school suspended Doe for five days. ${ }^{103}$ On the fifth day of the suspension, the district informed Doe's parents that they would pursue expulsion proceedings against Doe. ${ }^{104}$ The district expanded the suspension to last until they could hold a hearing on the expulsion, which was scheduled to take place nineteen days after the initial suspension. ${ }^{105}$

Doe's parents brought an action in District Court against the school and the State Superintendent of Public Instruction, alleging that the prolonged suspension and the expulsion violated the IDEA. ${ }^{106}$ Doe's parents sought a temporary restraining order preventing the school from conducting the expulsion hearing and requiring the school to hold an IEP meeting. The District

\begin{tabular}{|c|c|}
\hline 93 & Id. at 323 . \\
\hline 94 & See id. at $308,312$. \\
\hline 95 & Id. at 323 . \\
\hline 96 & See id. at $312-13$. \\
\hline 97 & Id. \\
\hline 98 & Id. at 312 . \\
\hline 99 & Id. at 313 . \\
\hline 100 & Id. \\
\hline 101 & $I d$. \\
\hline 102 & Id. \\
\hline 103 & California law at the time allowed a school to suspend any student for up to five days, unless the school \\
\hline was pursuing al & expulsion, in which case the school could continue the suspension up to the expulsion hearing. Id. \\
\hline 104 & $I d$. \\
\hline 105 & Id. \\
\hline 106 & Id. at $313-314$ \\
\hline
\end{tabular}


Court judge granted the injunctive relief, ordering the defendants provide home tutoring to Doe until the resolution of the matter. ${ }^{107}$ Not long after, the judge granted a preliminary injunction requiring the defendants to return Doe to his then-current educational placement, the school, under his last agreed upon IEP pending an IEP review. Doe had been out of school at that point for over twenty-four school days.

The second student, identified under the pseudonym Jack Smith, was similarly situated to John Doe. ${ }^{108}$ Smith was described as hyperactive, anxious, and impulsive, with low self-esteem but above-average intelligence. ${ }^{109}$ Smith's emotional disabilities exhibited themselves in uncontrolled verbal and sometimes physical outbursts. ${ }^{110}$ By the time Smith arrived at the public middle school pursuant to an IEP placement, he was participating in stealing, extortion of follow students, and making verbal provocations, particularly in the form of sexual comments to female students. ${ }^{111}$ Smith's primary caretakers were frequently apprised of Smith's disruptive behavior and informed that Smith would be expelled if these behaviors were not controlled. ${ }^{112}$

On November 14, 1980, Smith was expelled when he continued to make lewd comments after receiving multiple warnings. ${ }^{113}$ The matter was referred to the school district, which recommended expulsion. ${ }^{114}$ Just as in Doe's case, the district continued the suspension until the expulsion hearing could take place. ${ }^{115}$ Two weeks later, Smith's counsel fought these proceedings on the same grounds as Doe. ${ }^{116}$ However, in Smith's case the school agreed to cancel the expulsion hearing and return Smith to the school for half-days or to provide home tutoring. ${ }^{117}$ Smith's caretakers agreed to home tutoring, which began on December 10, 1980. ${ }^{118}$ Smith had been without any educational instruction for twenty-six days. ${ }^{119}$

Smith caught wind of Doe's nearly identical action and sought leave to intervene in Doe's suit. ${ }^{120}$ The District Court allowed Smith to join the suit, and thereafter granted summary judgment in favor of both students on their IDEA claims, issuing a permanent injunction preventing schools from suspending a student for more than five days for disability-related conduct. ${ }^{121}$ The court found that the indefinite suspensions and potential expulsions of the students for disability-related conduct violated the student's right to FAPE, and enjoined the defendants from effecting any change in placement of these students prior to the resolution of the IDEA proceedings. ${ }^{122}$

$\begin{array}{ll}107 & I d . \\ 108 & I d . \\ 109 & I d . \text { at } 314-15 . \\ 110 & I d . \text { at } 314 . \\ 111 & I d . \text { at } 315 . \\ 112 & I d . \\ 113 & I d . \\ 114 & I d . \\ 115 & I d . \\ 116 & I d . \\ 117 & I d . \\ 118 & I d . \\ 119 & \text { See id. } \\ 120 & I d . \\ 121 & I d . \text { at } 315-316 . \\ 122 & I d .\end{array}$


The defendants appealed to the Ninth Circuit, which affirmed the lower court's decision in part but held that a suspension of up to thirty days was not a "change in placement" and, therefore, did not violate the IDEA. ${ }^{123}$ Thereafter, Bill Honig, the California Superintendent of Public Instruction, sought review at the United States Supreme Court. ${ }^{124}$

At the Supreme Court, Honig asserted two primary arguments. First, that Congress could not possibly have excluded any dangerousness exception, explaining the absence in the IDEA by asserting "that Congress thought the residual authority of school officials to exclude dangerous students from the classroom too obvious for comment." Second, that Congress failed to provide a dangerousness exception through inadvertence and, therefore, court intervention was necessary. ${ }^{125}$ The petitioner asserted that any appeal process is necessarily lengthy given that an aggrieved party must exhaust administrative appeals. ${ }^{126}$ Further, the petitioner pointed to the fact that any court would be bound by stay put's automatic injunction. ${ }^{127}$

In rejecting both of these arguments, the Supreme Court concentrated on the plain language of the IDEA, noting the stay put provision contains a directive: "the child shall remain in the then current educational placement." 128 The Court also pointed to the lack of any language that would authorize a school district to exclude dangerous students. ${ }^{129}$ Although the Court acknowledged that this restricted a school district's ability to act independent of the courts, the Supreme Court was not persuaded. Harkening back to the Mills and PARC schemes prior to the IDEA, the court noted:

We think it clear... that Congress very much meant to strip schools of the unilateral authority they had traditionally employed to exclude disabled students, particularly emotionally disturbed students, from school. .. . Congress did not leave school administrators powerless to deal with dangerous students; it did, however, deny school officials their former right to 'self-help,' and directed that in the future the removal of disabled students could be accomplished only with the permission of the parents or, as a last resort, the courts. ${ }^{130}$

The Court noted that the IDEA allowed interim placements where school districts and parents could agree. ${ }^{131}$ This, according to the Court, was further evidence that Congress envisioned just this kind of scenario, but rejected giving the school any unilateral authority. ${ }^{132}$ The Supreme Court concentrated on the IDEA's rejection of school district's authority, contending that Congress did not intend to strip courts of their authority. ${ }^{133}$

\begin{tabular}{|c|c|}
\hline 123 & Id. at 316 . \\
\hline 124 & Id. at 317 . \\
\hline 125 & Id. at 323 . \\
\hline 126 & Id. at 326 . \\
\hline 127 & Id. \\
\hline 128 & Id. at 323 (citing 20 U.S.C. $\S 1415(\mathrm{e})(3)$ (emphasis in original), now found at 20 U.S.C. $\S 1415(\mathrm{j})$ ). \\
\hline 129 & $I d$. at $323-25$. \\
\hline 130 & Id. at $323-24$. \\
\hline 131 & Id. at 324-325 (citing 20 U.S.C. $\S 1415(\mathrm{e})(3)$ ). \\
\hline 132 & Id. \\
\hline 133 & $\begin{array}{l}\text { Id. at } 327 \text { ("The stay-put provision in no way purports to limit or pre-empt the authority conferred on } \\
\text { it says nothing whatever about judicial power") }\end{array}$ \\
\hline
\end{tabular}


Even in their decision, the Supreme Court acknowledged that the review procedures under the IDEA are "often lengthy." ${ }^{134}$ Nonetheless, the Court pointed to other procedures a school district can utilize, including "the use of study carrels, timeouts, determination, or the restriction of privileges." 135 In extreme circumstances, a school district could suspend a student for up to ten days, providing a "cooling down' period during which officials can initiate IEP review and seek to persuade the child's parents to agree to an interim placement." ${ }^{136}$ The Court noted that if this fails, a school district may appeal to the help of the courts. ${ }^{137}$

In a decision that would later become extremely important for any party attempting to fight a stay put placement, the Court held that the aggrieved party "may bypass the administrative process where exhaustion would be futile or inadequate." 138 The Court noted that they had "no reason to believe that Congress meant to require schools alone to exhaust in all cases, no matter how exigent the circumstances." ${ }^{139}$ However, in these circumstances the burden would be on the school to prove both (1) that an administrative process would be futile or inadequate, and (2) that a student must be removed because maintaining the child in their current educational placement is "substantially likely to result in injury either to himself, or to others." 140

Finally, the Court overturned the lower court's ruling that a suspension of up to thirty days did not violate the IDEA's stay put provision. ${ }^{141}$ The Court held that a suspension of more than ten school days constituted a "change in placement" and thus violated the IDEA's stay put provision. ${ }^{142}$

\section{DURATION OF STAY PUT PLACEMENT}

As Honig indicates, after the IDEA was enacted the schools, parents, and courts struggled to comply with the new framework. This necessarily meant that some disagreements about the provisions of the Act would need to be worked out through the court system. The stay put provision was no exception. Although initially litigation surrounding stay put was relatively sparse, the growing complexity of the special education landscape has brought with it a new string of cases, in particular those involving stay put. ${ }^{143}$ Unfortunately, there is still much disagreement among the Circuit Courts as to many aspects of stay put. This uncertainty has often resulted in just the kind of situations that the IDEA attempted to remedy, namely children receiving inadequate educational services, remaining in inappropriate placements, or even being educated at home instead of in the classroom.

Clearly, the IDEA is a complex statute, and necessarily so. As such, there are elements within the details of the statute that will require clarification and alteration with the changing

\begin{tabular}{|c|c|}
\hline 134 & Id. \\
\hline 135 & Id. at 325 . \\
\hline 136 & Id. at 326 . \\
\hline 137 & Id. \\
\hline 138 & Id. at 327 . \\
\hline 139 & Id. \\
\hline 140 & Id. at $327-328$. \\
\hline 141 & Id. at $328-29$. \\
\hline 142 & See 20 U.S.C. $§ 1415(\mathrm{~K})(1)(\mathrm{B})(2004)$; see also Honig, 484 U.S. at 328-329. \\
\hline 143 & See St. Johnsbury Acad. v. D.H., 240 F.3d 163, 166, 171 (2d Cir. 2001); Koehler v. Juniata Cty. Sch. Dist. \\
\hline
\end{tabular}


educational landscape over time. Of the many unresolved issues surrounding the IDEA, and stay put in general, perhaps none is as pressing as the length of time a stay put placement is meant to last.

Under the IDEA, stay put applies pending the resolution of the dispute. ${ }^{144}$ Like many aspects of the statute there is no further guidance as to what this means. Practically, this leads to the question: Does the resolution of the dispute occur at the end of the administrative hearing, the first appeal, or only after the exhaustion of all legal remedies, including, at the most extreme, appeal to the United States Supreme Court? If the latter, is the student truly meant to maintain the same placement while the case is litigated? Circuit Courts are divided, with some holding that stay put applies through the district court review, and others holding that stay put placements apply throughout the proceedings through the Circuit Courts. The choice between these options can mean a difference of months or, increasingly likely, years.

As other articles have observed, the unresolved issues surrounding stay put may also lend themselves to abuse. "[A] competent lawyer may use, although arguably unethically, the same complexity of IDEA to drag out the process in order to keep the student in school." 145 A parent could claim the stay put protection for his or her child and utilize the administrative and judicial process to lengthen the child's time at the desired private school at public expense, despite the cost to the state and the inappropriateness of the placement. ${ }^{146}$ Students could, and have, stayed in their stay put placements until their twenty-first birthday, when the issue ultimately becomes moot. ${ }^{147}$

As explored in more detail below, the consequences of a stay put placement can be farreaching. An extended stay put placement could mean a student receives inappropriate or inadequate services for a significant period of time. A student may face increasingly restrictive services as the school staff attempts to accommodate a potentially inappropriate placement.

Student's needs necessarily grow and change as they age. This basic human development fact is important not only for regular education students, but arguably more so for special education students. This is why the drafters of the IDEA required annual review of IEPs for each year the student is eligible for special education services. ${ }^{148}$ Yet during a stay put placement, the IEP stays the same ${ }^{149}$, which can greatly impact students and schools alike. Importantly, a lengthy stay put placement may also mean the safety of students and/or staff is put in jeopardy.

\section{A. Circuit Court Split on the Duration of Stay Put Obligations}

Circuit Courts are split on the issue, greatly complicating this scheme. While the D.C. Circuit and the Sixth Circuit have held that the stay put obligation extends only through the district court review, ${ }^{150}$ the First Circuit, Third Circuit, Ninth Circuit, and a New Jersey District Court, have

\footnotetext{
144 See 20 U.S.C. $\$ 1415(\mathrm{j})$.

145 Trent D. Nelson false, Congressional Attention Needed for the "Stay-Put" Provision of the Individuals with Disabilities Education Act, 1997 BYU EDUC. \& L. J. 49, 61 (1997).

146 See id. at 52; Petition for Writ of Certiorari Ridley School Dist. v. M.R., 2014 WL 2902200 (U.S.), 12 ("Geographical happenstance should not dictate whether state and local governments must bear the heavy financial burden of funding a private educational placement that both a trial and appellate court have ruled unnecessary.").

147 See id. at 60.

148 See 20 U.S.C. 1414(d)(4)(A)(i) (2016).

149 Unless the parents and district agree otherwise.

150 See Andersen v. Dist. of Columbia, 877 F.2d 1018 (D.C. Cir. 1989); Kari H. v. Franklin Special Sch. Dist.,
} 
all held that the stay put obligation extends through an appeal to the circuit courts. ${ }^{151}$

Both interpretations find support in the IDEA and implementing regulations. For instance, in finding that stay put applies during all administrative and judicial proceedings, the Third Circuit noted that " $[\mathrm{t}]$ he statute's text is broadly written to encompass 'the pendency of any proceedings conducted pursuant to this section.' Narrowing the provision's scope to exclude the appellate process strikes us as an unnatural reading of such expansive language." 152 The court held that their interpretation best complied with the overall purpose and object of the Act. "We cannot sensibly find that a FAPE dispute is 'ultimately resolved' before proceedings have run their course through a final, unappealed decision by an administrative body or an appellate judicial decision." 153 The Court pointed to the implementing regulation, which utilized the same broad language of "any ... . judicial proceeding regarding a due process complaint." 154

However, the Sixth Circuit, in finding the stay put provision applies only through appeal to the district court, concentrated on the fact that the section of the IDEA where the stay put provision is found, 20 U.S.C. $\S 1415$, only mentions three types of proceedings: "(1) due process hearings; (2) state administrative review; and (3) civil actions for review brought in either state or federal district court." 155 The Sixth Circuit reasoned that "[a]lthough an appeal is part of a "civil action,' the statutory language suggests that Congress intended the stay-put provision to apply only during actions in these three forums. If Congress wanted the provision to apply during appeals to the circuit courts, it certainly could have said so." 156 Harkening back to Honig v. Doe, the Sixth Circuit further found that the purpose of the stay put provision would not be furthered by the other Circuits' approach:

In Honig v. Doe, the Supreme Court explained that one of the purposes of the stay-put provision was to protect children from unilateral displacement by school authorities... pending completion of review proceedings. This purpose, however, is not implicated once the district court has approved the proposed change in the child's placement; the change is not the result of unilateral action by school authorities. ${ }^{157}$

Frustratingly, although the United States Supreme Court recently accepted briefs on this very subject, the Supreme Court ultimately declined to hear the case. ${ }^{158}$

1997 U.S. App. LEXIS 21724, 1997 WL 468326 at *6 (6th Cir. Aug. 12, 1997) (unpublished opinion); Bd. of Educ. v. Johnson, 2008 U.S. Dist. LEXIS 95995, 2008 WL 5043472 at*4 (D. Del. Nov. 25, 2008).

151 See M.R. v. Ridley Sch. Dist., 744 F.3d 112, 115 (3d Cir. 2014); Joshua A. v. Rocklin Unified Sch. Dist., 559 F.3d 1036, 1038 (9th Cir. 2009); Ringwood Bd. of Educ. v. K.H.J., 469 F. Supp. 2d 267, 271 (D.N.J. 2006).

152 Ridley, supra note 151, at 125 (internal citations omitted).

153 Id. at 126

154 Id., citing 34 C.F.R. $§ 300.518$ (a) (emphasis added).

155 Kari ex rel. Dan H. v. Franklin Special Sch. Dist., 1997 U.S. App. LEXIS 21724 at*18-19 (6th Cir. Aug.

13, 1997).

$156 \quad$ Id. at $* 18$.

157 Id. at $* 19$.

158 M.R. v. Ridley Sch. Dist., supra note 151, at 115. 


\section{B. Educational Consequences of a Lengthy Stay Put Placement}

When parents invoke stay put, the student may only receive the services on their last accepted IEP. ${ }^{159}$ While parents and a school district may agree to alter the services the student receives or the placement of the student, stay put is often invoked when the school district and the parents cannot agree on the services provided. If the parents or school are particularly litigious, a dispute could last for years, keeping the child in the placement that the school ultimately determined was no longer appropriate. Under the current scheme, a student could be stuck with an older IEP that is no longer appropriate.

Given the IDEA's mission to provide a free, appropriate education to students with disabilities, the invocation of stay put has the potential of creating a contradictory situation in which a student does not receive appropriate services for significant periods of time. Although all parties may often have the student's best interests at heart, a student may nonetheless be denied appropriate services while the parents, the school, and/or the school district fight it out in court.

\section{Safety Consequences of a Lengthy Stay Put Placement}

Of paramount concern is school safety. A student who may once have been deemed appropriate for placement in a regular education classroom might begin to exhibit manifestations of his disability that compromises his own safety or the safety of others. ${ }^{160}$ For instance, a student might gradually become more violent and begin hitting, biting, or threatening other students, teachers or administrators. Or, a student might develop pica ${ }^{161}$ or begin running from staff (sometimes referred to as "bolting"), thus endangering himself or herself. Even if the manifestations of his or her disabilities do not change, a student might simply grow too large to be physically controlled by teachers and might require more specially trained teachers or aides.

It is not uncommon for parents, school districts, and, where applicable, private schools, to disagree over the changing nature of the student's disability. Parents may, understandably, balk at sending their child who was once appropriately placed in a regular education classroom to a special education classroom or school. Conversely, school districts may not want to pay for more services they do not believe are appropriate. In any of these scenarios, a student may need to be moved to a different placement not anticipated in their last accepted IEP.

When considering this framework in relation to student safety, this becomes even more troubling. The reality of the current education system under the IDEA is that imposition of stay put placements can create untenable situations in which the safety of students and staff are compromised.

Examples are helpful to demonstrate how this could occur. Consider a situation where the student is engaging in increasingly concerning and potentially dangerous behavior. The parents

\footnotetext{
15920 U.S.C. $\S 1414$ (d)(4)(A)(i). The IDEA requires the Team to review the IEP "not less frequently than annually."

160 "Perhaps the most dynamic effect of the stay-put provision is the potential harm to other students from a dangerous disabled student who is not immediately removed." Trent D. Nelson false, Congressional attention needed for the "stay put" provision of the Individuals with Disabilities Education Act, supra note 145, at 58.

161 An eating disorder in which a person ingests non-nutritive items, which can be exhibited by eating items such as plastic, drywall, or metal objects. See American Psychiatric Association. (2013). Diagnostic and statistical manual of mental disorders: DSM-5(5th ed.). Arlington, VA: American Psychiatric Association.
} 
believe that the student needs to be placed in a more restrictive setting, possibly with an aide or in a private special education school. The school district disagrees and refuses to pay for either of these options. The student's stay put placement is that original classroom until the matter has been fully litigated despite the inappropriateness of the placement. Parents may unilaterally move their child to a different, private placement, but they must bear the financial burden until the litigation has completed. ${ }^{162}$ Further, if the parents do not prevail, they remain financially responsible. ${ }^{163}$ This burden is, understandably, impossible for many parents to bear.

Consider a similar scenario where a publically-funded student in a private special education school engages in assaultive behavior toward other students. The manifestation of the student's disability has changed, and he or she has become increasingly violent. Where once the staff could control the student, the student is now fully grown and cannot be restrained by staff members. The private school believes the student is no longer appropriate for their program, and attempts to work with the parents and the school district to alter their placement to a school more appropriate to the student's needs and more able to provide for a safe environment. Yet the parents disagree. The parents respond by filing a claim with the administrative agency requesting a stay put placement at the current school along with claims of violations of the IDEA. In this scenario, the student has the potential to be enrolled in the same school for months or even years while this is litigated.

If the school truly feels the student is a risk, they may proceed to the administrative agency to attempt to get a temporary change in placement by proving there is a health or safety risk. They may lose. Even if they are successful, simply getting a ruling takes time. And the parents still have the right to appeal that decision to the state or federal courts, and pursue that appeal until they have exhausted all of their legal remedies. Meanwhile, the student will remain in the school pending the resolution of the dispute. Finally, and importantly, any alteration in placement cannot exceed fortyfive days under this safety exception, and that is only after the school has proven that the placement is substantially likely to result in injury. ${ }^{164}$

It goes without saying that schools have a duty to provide a safe learning environment for not only that student, but also for the other students, faculty, and staff in the school. ${ }^{165}$ Yet, the stay put provision can, and often does, create an untenable situation where an entire school may be at risk. Congress's attempt to remedy the unilateral exclusion of the students from classrooms and to curb the authority of school districts has resulted in situations where students may very well be worse off than they were prior to the enactment of the IDEA. Allowing a student to remain in a placement that is not safe, or where the student is unable to receive appropriate education services, is clearly not in anyone's best interest. As one author put it, "[v]iolence in schools is simply too big of a problem to allow exceptions." 166

Highlighting the importance Congress placed on this provision through the IDEA's three

162 Sch. Comm. of Town of Burlington, Mass. v. Dep’t of Educ. of Mass., 471 U.S. 359, 373 (1985); Forest Grove Sch. Dist. v. T.A., 557 U.S. 230, 246 (2009).

163 Id.

16420 U.S.C. $\S 1415(\mathrm{k})(1)(\mathrm{G})$. Schools may also seek to remove a student who brings a weapon, drugs, or inflicts serious bodily harm for up to 45 days. $I d$.

165 Further, it is important to note that teachers may need to devote additional time and energy to these students, taking this time and energy away from other students. Congressional Attention Needed, supra note 145, at 58.

166 Zykorie, supra note 12, at 133. 
major revisions, the stay put provision has remained largely unchanged. ${ }^{167}$ The original text of the stay put provision in 1975 read:

(e) (3) During the pendency of any proceedings conducted pursuant to this section, unless the State or local educational agency and the parents or guardian otherwise agree, the child shall remain in the then current educational placement of such child, or, if applying for initial admission to a public school, shall, with the consent of the parents or guardian, be placed in the public school program until all such proceedings have been completed. ${ }^{168}$

The text of IDEA as it currently stands, after the 2004 amendments, reads:

(j) Except as provided in subsection (k)(4), during the pendency of any proceedings conducted pursuant to this section, unless the State or local educational agency and the parents otherwise agree, the child shall remain in the then-current educational placement of the child, or, if applying for initial admission to a public school, shall, with the consent of the parents, be placed in the public school program until all such proceedings have been completed. ${ }^{169}$ (emphasis added). Aside from very minor changes, the stay put language has remained virtually unchanged. ${ }^{170}$ Yet the issues surrounding school safety have changed since the enactment of the IDEA in 1975. With issues of safety and appropriate education in mind, many have urged Congress to make alterations to the stay put provision of the IDEA.

\section{A Recommendation for a Shorter Period of Time}

The disagreement among state and circuit courts makes clear that there must be some congressional or DOE action clarifying how long stay put placements last. Lengthy resolutions of parent-school disagreements over the student's placement and services have left entire school communities exposed to inappropriate and even dangerous placements for protracted periods. The student in need of special services assured by the IDEA is often left instead with a frozen IEP while the problems are hashed out in administrative and court proceedings.

The DOE should publish a rule in the Code of Federal Regulations clarifying the length of time stay put placements may last. Further, Congress must clarify the length of time any stay put

167 One of the only changes that altered stay put placements was the 2004 change that made IAES placement the "stay put" placements when a parent contests the MDR, IAES services, or the discipline. 20 U.S.C. § 1415(k)(1)(B-G). This essentially means that if a parent files a complaint in these circumstances, the placement for the child will be the IAES placement. It is interesting to note, however, that in the past at least some courts had "not consistently applied the stay-put provision for conduct that is not a manifestation of the student's disability." Congressional Attention Needed, p. 53.

$168 \quad 20$ U.S.C. $\S 1415(\mathrm{e})(3)(1975)$.
16920 U.S.C. $\S 1415(\mathrm{j})$.

170 While the text of stay put has not changed, one significant change to the way interim alternative education services (IAES) are handed has resulted in one change to stay put. The new IDEA language makes the "stay put placement" the IAES in situations where parents contest the MDR after a finding that the student's conduct was not the result of their disability, the stay put provision has not changed. 
placement can be in effect by amending the text of the IDEA.

In determining which circuit to side with, there is a strong policy argument for limiting the placement. Given the seriousness of the potential consequences of an inappropriate stay put placement, a shorter period of time for the first appeal better ensures both safety and stability. ${ }^{171}$ This approach balances the needs of the student for stability and ensures continual education services, while acknowledging that lengthy stay put placements may keep a student in an inappropriate and unsafe setting. ${ }^{172}$

By limiting the amount of time a stay put placement is in effect, this approach discourages abuse of the stay put placement by parents by limiting it in time. ${ }^{173}$ It has the added benefit of preventing the abuses by school districts that gave rise to the stay put provision in the first place, namely the periodic expulsion and suspension of "trouble" students. ${ }^{174}$

\section{THE STAY PUT PROVISION AND PRIVATE SCHOOLS}

There have been great advancements in our understanding of how to best educate children with disabilities. These specialized approaches have led to increasingly better education standards for students with disabilities, and have allowed many children to enjoy the educational success envisioned by the IDEA.

A natural corollary to these specialized approaches is the creation of more specialized schools, which is where special education private schools come into play. ${ }^{175}$ Whereas a student previously might be educated solely in a special education classroom, whole schools now exist that cater to a single disability. For instance, most would agree that a student with a severe learning disorder and another with more pronounced physical and mental impairments, while both deserving of education services, will nonetheless require entirely different services. By sending these students to specialized private schools, public schools can better guarantee access to FAPE and, in some cases, reduce the financial burden of attempting to provide individualized care.

The drafters recognized that it would be cost prohibitive and in some cases impossible for all public schools to attempt to accommodate every student's disability. ${ }^{176}$ Similarly, students may be unable to receive appropriate education services without very specialized form of instruction or specially trained aides that local public schools are simply unable to provide. ${ }^{177}$ This is particularly true for those students with uncommon manifestations of their disabilities, or who require more

171 See Petition for a Writ of Certiorari, Ridley School Dist. v. M.R., 2014 WL 2902200 (U.S.), 25

172 See Trent D. Nelson false, Congressional Attention Needed for the "Stay-Put" Provision of the Individuals with Disabilities Education Act, 1997 BYU EDUC. \& L.; Petition for a Writ of Certiorari, Ridley School Dist. v. M.R., 2014 WL 2902200 (U.S.), 25.

$\begin{array}{ll}173 & \text { Id. } \\ 174 & \text { See id. }\end{array}$

175 While a small number of specialized public and private schools existed prior to the twentieth century, the number has grown exponentially over the years. See Martin L. Lavor, "Federal Legislation for Exceptional Persons: A History," Public Policy and the Education of Exceptional Children, published by The Council for Exceptional Children, Library of Congress Catalog Card Number 75-42938 (1976).

176 See Sch. Comm. of Town of Burlington, Mass. v. Dep't of Educ. of Mass., 471 U.S. 359, 369 (1985).

177 "The Act contemplates that such education will be provided where possible in regular public schools, with the child participating as much as possible in the same activities as nonhandicapped children, but the Act also provides for placement in private schools at public expense where this is not possible." Id. at 369. 
attention and care than other students. Many of these schools are specialized to provide educational services to students with certain specific disabilities.

Under the IDEA, school districts are authorized to place students in these private special education schools when they are unable to provide the student with FAPE. ${ }^{178}$

These are often referred to as "publically funded placements." Importantly, these publically funded private school students cannot lose any rights in this transfer. ${ }^{179}$ School districts are still under an active obligation to ensure that the students receive a free, appropriate education in the least restrictive environment. ${ }^{180}$ The IEP meetings are still held with representatives from the school district, only in these circumstances they also include the private school staff. ${ }^{181}$

As with any student receiving special education services, disputes often arise concerning the appropriateness of the services or the placement. Parents, school districts, and the private schools often disagree about what is in the best interests of the student. ${ }^{182}$ Students' capacities and manifestations of their disability may change, requiring an alteration in the services or, as sometimes occurs, the placement. The private school may feel, nonetheless, that the student is no longer an appropriate fit for the school.

While there may be other private schools more appropriately suited to the student's changing needs, getting the student to that other school can involve a lengthy process, including an IEP meeting, applications to alternative schools, and obtaining the consent of both the parents and the school district. ${ }^{183}$ Often, the parties cannot reach an agreement as to whether the student is still appropriately placed at the private school or whether the services must be changed within the school. This is typically when stay put is invoked.

The application of stay put placements to private schools is a growing and still unresolved issue. As with so many other aspects of the IDEA, the text itself is unclear. Caselaw offers no guidance. ${ }^{184}$ Yet this issue, in particular considering the length of time a stay put placement may last, can have serious and lasting effects on students. Considering the specialized services these students require, the risk is even greater that any failure in providing appropriate services could result in the opposite of what the IDEA was enacted to protect - access to appropriate education services. ${ }^{185}$

\footnotetext{
17820 U.S.C. $\S 1412(\mathrm{a})(10)(\mathrm{B})$.

179 See Department of Education; Children with Disabilities in Private Schools Placed or Referred by Public Agencies, 71 Fed. Reg. 156, 46598-9 (August 14, 2006) (codified at 34 C.F.R. Pt. 300.507) (emphasis added).

18020 U.S.C. $\$ 1412$ (a)(10)(B).

181 See id.

182 See Sara A. Gelser, Special Education Conflict: A Symptom of Poor Outcomes for Students, GP SOLO, Vol. 31 No. 2 (March/April 2014), found at https://www.americanbar.org/groups/gpsolo/publications/gp_solo/2014/ march_april/special_education_conflict_symptom_poor_outcomes_students.html [perma.cc/Y7HG-WABD].

18320 U.S.C. $\$ 1412$ (a)(10).

184 See Andersen v. Dist. of Columbia, 877 F.2d 1018 (D.C. Cir. 1989); Kari H. v. Franklin Special Sch. Dist., 1997 U.S. App. LEXIS 21724, 1997 WL 468326 at *6 (6th Cir. Aug. 12, 1997) (unpublished opinion); Bd. of Educ. v. Johnson, 2008 U.S. Dist. LEXIS 95995, 2008 WL 5043472 at*4 (D. Del. Nov. 25, 2008); M.R. v. Ridley Sch. Dist., 744 F.3d 112, 115 (3d Cir. 2014); Joshua A. v. Rocklin Unified Sch. Dist., 559 F.3d 1036, 1038 (9th Cir. 2009); Ringwood Bd. of Educ. v. K.H.J., 469 F. Supp. 2d 267, 271 (D.N.J. 2006).

185 See Trent D. Nelson false, Congressional Attention Needed for the "Stay-Put" Provision of the Individuals with Disabilities Education Act, 1997 BYU EdUC. \& L.; Petition for a Writ of Certiorari, Ridley School Dist. v. M.R., 2014 WL 2902200 (U.S.).
} 


\section{A. Arguments Against the Application of Stay Put to Private Schools}

The IDEA binds public schools, as operators of the state, but makes no mention of binding private organizations. After all, private schools are just that- private. There are several reasons, and substantial evidence, to suggest that Congress did not intend the IDEA to apply to private schools.

Private schools also point to the myriad of cases holding that private schools are not rendered "public" or even "quasi-public" when they contract with public schools. ${ }^{186}$ Although federal and state government money flows to private schools for a variety of education-related purposes, including these publically funded students, the courts have not considered this sufficient to render a private school "public.". 187

Looking back to the creation of the IDEA, the application of these principles to private schools makes less sense. The drafters of the IDEA were concerned that public schools would unilaterally expel or suspend special education students, leaving these students with no access to education services (unless they were wealthy enough to afford private schools on their own). ${ }^{188}$ The IDEA envisioned a free public education where every student had access to appropriate services. When public schools were denying students access to services, these students were often left without any services.

In the event that a private school expels a student, the student can always go back to the public school. ${ }^{189}$ Clearly this is not an ideal situation, as the public school must have believed that they could not provide appropriate services, or else they would not have sent the student to private school in the first place. Nonetheless, the student and school are not without options. The school district may look for other private school placements. ${ }^{190}$

Yet, private schools exist in a different framework. Private schools are not authorized to place a student in a permanent alternate placement - the private school is not in a position to send the student to another private school without the school district's involvement and the parent and school district's support. ${ }^{191}$ The same applies to the addition of services. Private schools are, unlike public schools, relatively powerless to adopt alternative options in the face of an inappropriate placement. ${ }^{192}$

Recognizing that the text of the IDEA does not resolve this issue, the Federal Department of Education ("DOE") responded to this issue in a "comment and answer" section of the Federal Register in 2006. ${ }^{193}$

186 See e.g. Rendell-Baker v. Kohn, 457 U.S. 830 (1982); Nkwuo v. Angel, 693 F. App'x 696 (9th Cir. 2017)(upholding lower court decision); L.P. v. Marian Catholic High Sch., 852 F.3d 690, 694 (7th Cir. 2017); Robert S. v. Stetson Sch., Inc., 256 F.3d 159, 161 (3d Cir. 2001).

187 Id.

188 See Edwin Martin, Reed Martin, Donna Terman, The Legislative and Litigation History of Special Education, 6 THE FUTURE OF CHILDREN, Spring 1996, no. 1, at p. 26

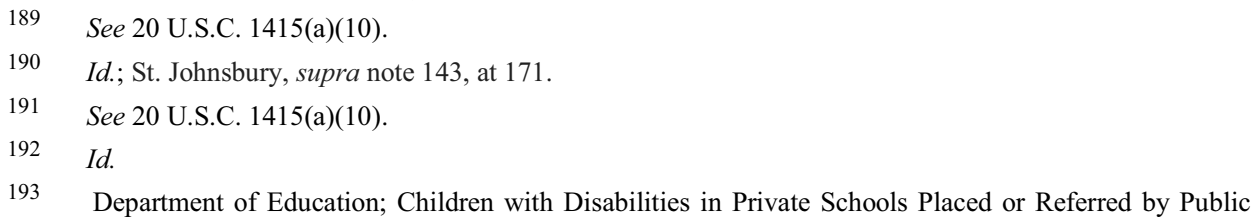
Agencies, 71 Fed. Reg. 156, 46598-9 (August 14, 2006) (codified at 34 C.F.R. Pt. 300.507) (emphasis added). 
Comment: A few commenters recommended requiring States to have rules, regulations, and contracts requiring private schools that accept publicly-placed children with disabilities to guarantee that children with disabilities receive FAPE and their parents retain all of the protections mandated for public schools, including the right to pendency placements if the parents challenge the decisions of the private school to terminate the children's placements. One commenter recommended that the regulations clarify that private schools serving children placed by a public agency are not exempt from the obligation to provide FAPE.

Discussion: The Act does not give States and other public agencies regulatory authority over private schools and does not place requirements on private schools. The Act imposes requirements on States and public agencies that refer to or place children with disabilities in private schools for the purposes of providing FAPE to those children because the public agency is unable to provide FAPE in a public school or program. The licensing and regulation of private schools are matters of State law. The Act requires States and public agencies, including LEAs, to ensure that FAPE is made available to all children with disabilities residing in the State in mandatory age ranges, and that the rights and protections of the Act are extended to eligible children and their parents. If the State or public agency has placed children with disabilities in private schools for purposes of providing FAPE to those children, the State and the public agency must ensure that these children receive the required special education and related services at public expense, at no cost to the parents, in accordance with each child's IEP. It is the responsibility of the public agency to determine whether a particular private school in which the child with a disability will be placed for purposes of providing FAPE meets the standards that apply to the SEA and LEA and that a child placed by a public agency be afforded all the rights, including FAPE, that the child would otherwise have if served by the public agency directly. ${ }^{194}$

This clearly places the burden on the school district to ensure that all of the mandates of the IDEA are followed, even when the school district places a student in a private school at public expense. The language from this section strongly supports the contention that private schools are not subject to the stay put requirement. Another "comment and discussion" section further supports this interpretation:

Discussion: We do not agree that the change requested by the commenter is necessary. Section $615(\mathrm{j})$ of the Act and $\S 300.518$ provide that during the pendency of any administrative or judicial proceeding regarding a due process complaint under $\S 300.507$, except as provided in $\S 300.533$, unless the parent and the SEA or LEA agree to a proposed change in the educational placement of the child, the child remains in the current educational placement. Implicit in maintaining a child's current educational placement is the requirement that the

194 Department of Education; Children with Disabilities in Private Schools Placed or Referred by Public Agencies, 71 Fed. Reg. 156, 46598-9 (August 14, 2006) (codified at 34 C.F.R. Pt. 300.507) (emphasis added). 
public agency must ensure that FAPE continues to be made available to the child. ${ }^{195}$

Although not dispositive, the DOE clearly mandates that the school district is the party responsible for ensuring that FAPE is provided to privately placed, publically funded students. ${ }^{196}$

Further supporting this argument is the fact that school "placement" is not considered location-specific under the IDEA. ${ }^{197}$ This may seem, on its face, to be illogical. How can a placement not mean a specific place such as a school? Regardless of the wording, courts and the Department of Education have consistently defined placement as including the IEP and services, but not the specific brick and mortar school:

The term "current placement" is not readily defined. While it includes the IEP and the setting in which the IEP is implemented, such as a regular classroom or a self-contained classroom, the term is generally not considered to be locationspecific. ${ }^{198}$

Several federal interpretations of the issue have concluded that the "current educational placement" is not location-specific. On the U.S. Department of Education website for IDEA, a "discussion" note states that "[t]he child's current placement is generally not considered to be location-specific." 199

This lends itself to the argument that the IDEA mandates for stay put do not apply to private schools. Private schools argue that if the stay put "placement" envisioned by the IDEA means only those services, then it seems perfectly logical that pending the resolution of any dispute, the public school could continue to provide these services without imposition of the student on the private

\footnotetext{
195 Id. at 46709 (emphasis added).

196 See also id. at 46599 (emphasis added):
}

Comment: One commenter stated that, in cases where the public agency places a child in a private school or residential treatment facility for the purposes of providing FAPE, the public agency should be required to determine and inform the private school or residential treatment facility about the person or persons who have the legal authority to make educational decisions for the child.

Discussion: The change requested by the commenter is not needed because the public agency, not the private agency, is responsible for providing FAPE to a child who is placed by the public agency in a private school. Consistent with $\S 300.146$ and section 612(a)(10)(B) of the Act, a public agency that places a child with a disability in a private school or facility as a means of carrying out the requirements of Part B of the Act, must ensure that the child has all the rights of a child with a disability who is served by a public agency. . . .

Private schools have also pointed to cases standing for the proposition that federal agencies are in the best position to interpret federal law. See, e.g., Orthopaedic Hosp. v. Belshe, 103 F.3d 1491, 1495-6 (9th Cir. 1997).

197 See Federal Register, Vol. 71 No. 156, p. 46709 (2006); Office of Special Education Programs (“OSEP”) letter dated November 30, 2007 on the topic Least Restrictive Environment.

198 Department of Education; Assistance to States for the Education of Children with Disabilities and the Early Intervention Program for Infants and Toddlers with Disabilities, 64 Fed. Reg. 12406-01, 12616 (March 12, 1999) (codified at 34 C.F.R. Pt. 300.518).

199 U.S. Department of Education, Building the Legacy: IDEA 2004, http://idea.ed.gov/explore/view/p /,root,regs,preamble2,prepart2,E,3324,.html [perma.cc/34FP-5XEU]. 
school itself.

\section{B. Arguments in Favor of the Application of Stay Put to Private Schools}

Although the Federal Register analysis appears to be dispositive, school districts have pushed back against any interpretation of the IDEA that does not apply the mandates of stay put to private schools with publically funded students. They assert that the purposes behind stay put, and the IDEA in general, would be undermined if it did not apply to publically placed private school students. ${ }^{200}$ If stay put does not apply in these circumstances, a situation could arise where a student is moved between several schools during a dispute, or is simply without services or in an IAES, a situation the IDEA clearly intended to avoid. ${ }^{201}$ This may occur when a student requires such specialized services that a public school is unable to provide such services to the student, even with the addition of staff or the alteration of the program.

School districts also have asserted that the private school, by contracting with the school district, enters into a contractual arrangement where the private school is required, per the terms of the contract, to abide by the IDEA's regulations. ${ }^{202}$ Although states accept money from the federal government in exchange for complying with the IDEA, private schools do not. However, the argument has been made that private schools, upon accepting publically funded students with this money, subject themselves to the mandates of the IDEA by de facto accepting this money. ${ }^{203}$

\section{Caselaw Offers No Clear Answer}

Caselaw is sparse on this issue. Until recently, courts have not had to confront this issue often, and indeed, many of these disagreements are resolved at the administrative level.

Of the courts that have considered the issue, most have determined that the IDEA's stay put provision does not apply to private schools. ${ }^{204}$ For instance, in St. Johnsbury Academy v. D.H, the court addressed whether private schools are subject to the mandates of the IDEA. ${ }^{205}$ Although not specifically considering the issue of stay put's application to private schools, the larger issue nonetheless encompasses the stay put question.

In Johnsbury, the St. Johnsbury School District did not have a public school. The district either placed students at the local private school, St. Johnsbury Academy ("the Academy"), or at public schools outside of the district. ${ }^{206}$ The student in the case, D.H., had cerebral palsy, vision issues, and a learning impairment. ${ }^{207}$ D.H.'s IEP required that he be "mainstreamed" in regular classes in at least two subjects. ${ }^{208}$ After D.H. completed his eighth grade year in a public middle

\footnotetext{
200 P.N. v. Greco, 282 F. Supp. 2d 236 (D.N.J. 2003).

201 See Honig, supra note 92.

202 See St. Johnsbury, supra note 143, at 172.

203 See id.

204 See generally Koehler v. Juniata County Sch. Dist., 2008 U.S. Dist. LEXIS 32079 (US. Dist. Ct, MD, PA); St. Johnsbury, supra note 143, at 171; Ullmo, supra note 143, at 679.

205 St. Johnsbury Acad., 240 F.3d at 170 (2d Cir. 2001).

206 Id. at 165.

207 Id. at 166.

208 Id. at $166-67$.
} 
school, D.H. applied to the Academy. ${ }^{209}$ The Academy accepted D.H. into their "Individualized Services Program," and the placement was funded by the public school. ${ }^{210}$ Based on his testing, his placement involved educating D.H. in solely special education courses with no mainstream courses. ${ }^{211}$

D.H.'s parent objected to this placement as it failed to comply with D.H.'s IEP requirements and because it failed to conform with the IDEA's least restrictive environment requirement. ${ }^{212}$ When the Academy refused to alter their program, D.H.'s parent filed an administrative complaint. ${ }^{213}$ The Administrative Hearing Officer found in favor of D.H., holding that the IDEA required the Academy to place D.H. in regular classrooms according to his IEP. ${ }^{214}$ The district court upheld the Hearing Officer's decision, finding that the Academy, having accepted public funding, was required to conform to the IDEA standards and liable under the IDEA. ${ }^{215}$

On appeal, the Second Circuit reversed the lower court's ruling. Concentrating on the language of the IDEA and interpreting statutes, the Second Circuit held that the private school was not bound by the IDEA:

IDEA expressly contemplates that children will be "placed in ... [private] schools or facilities by the State or appropriate local educational agency as the means of" complying with the statute, and with respect to such children, the statute obligates the "State"--not the private school--to "ensure" that such children "are provided special education and related services, in accordance with an individualized education program." 216

Although the IDEA requires a student be placed in the least restrictive environment, the Second Circuit found that the IDEA clearly places the burden of enforcement on the LEA. ${ }^{217}$

The court concentrated on several aspects of the IDEA. The court noted that although the regulations require conformation with the IDEA's IEP and LRE requirements when students are publically placed in private school, the public agency nonetheless remains responsible for ensuring compliance. ${ }^{218}$ Further, the implementing rules are clear that they are "binding on each public agency in the State that provides special education and related services to children with disabilities." 219 Yet when the regulations consider the applicability of these rules to private schools, they only state that "each public agency in the State is responsible for ensuring that the rights and

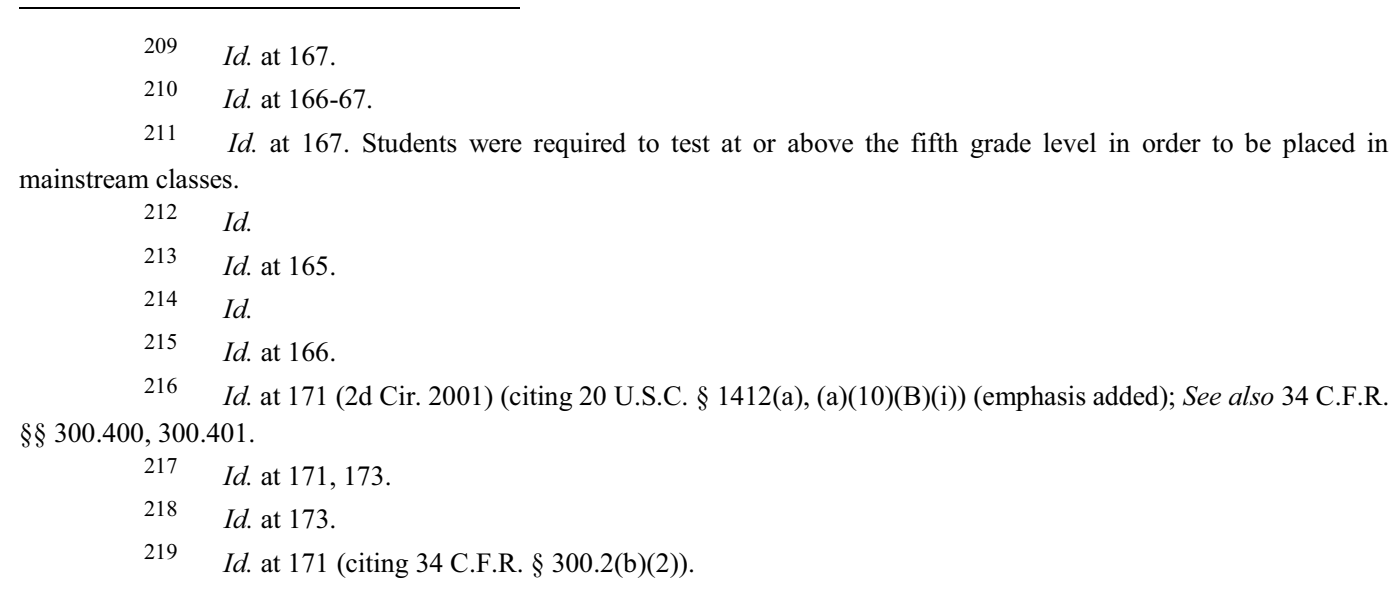


protections under [IDEA] are given to children with disabilities ... placed in private schools and facilities by that public agency." 220

The student argued that the Academy was acting as the school district ("local education agency") for the purposes of the IDEA, and should be treated as such. The court rejected this argument, finding that "[w]ith narrow irrelevant exceptions, an LEA is by definition a public entity (rather than a private one) and an administrative body (rather than a school itself)."221

However, the court did note that private schools and public agencies could contract in a way that confers some liability on the private school. Yet in this case, the public agency had not asserted any claim under that theory.

We do not mean to imply that arrangements between a public agency and a private school are not enforceable against the private school. Public agencies are the only entities directly responsible under IDEA, but one responsibility of such agencies is to 'make arrangements' for the implementation of IDEA standards with private institutions that are willing and able to strike a deal.... The regulations clarify that 'nothing in this part relieves an insurer or similar third party from an otherwise valid obligation to provide or to pay for services provided to a child with a disability. ${ }^{, 22}$

This ruling leaves open the possibility that private schools could incur liability under the IDEA through certain contractual arrangements.

This idea was picked up in a case decided just two years later, P.N. v. Greco. ${ }^{223}$ The student, J.N., was described as "fragile" and easily frustrated, with anxiety issues that sometimes prevented him from attending school. ${ }^{224} \mathrm{~J} . \mathrm{N}$. was placed by the school district at Winsor, a private school. ${ }^{225}$ Although initially he did well, in his second year J.N. did not get along with his teacher. ${ }^{226}$ The result was that J.N. was frequently absent from school and his parents were often calling the school. ${ }^{227}$ Winsor claimed these constant disruptions made it impossible for the school to comply with J.N.'s IEP, and terminated J.N. ${ }^{228}$

Although J.N. was successfully placed in a different private school, the parents of J.N. nonetheless filed an administrative complaint alleging that the Board of Education and the private

220 Id. (citing 34 C.F.R. $\S 300.2(\mathrm{c})(1))$.

221 Id. at 172 (stating that “. . among the functional differences between private schools and LEAs, LEAs are entitled to receive at least $75 \%$ of a state's IDEA monies on the condition that they provide a FAPE to disabled students in their jurisdictions. $\S 1411(\mathrm{~g})(1), 1413(\mathrm{a})(1)$. A private school has no such entitlement.”).

$222 \quad I d$. at 172-3 (citing 34 C.F.R. § 300.554). See Id. § 300.301(a) (stating that "a State may use whatever ... private sources of support are available in the State to meet the requirements of this part.”); See id. § 300.302 (authorizing the placement of a disabled child in "a public or private residential program" when "necessary to provide special education and related services”). 34 C.F.R. $\S 300.301(\mathrm{~b})$.

$\begin{array}{ll}223 & \text { See Greco, supra note 200, at } 221 . \\ 224 & \text { Id. at } 226 . \\ 225 & \text { Id. } \\ 226 & \text { Id. at } 227 . \\ 227 & \text { Id. } \\ 228 & \text { Id. }\end{array}$


school had improperly terminated J.N., violating the IDEA by failing to give appropriate notice of the termination, and failing to properly convene an IEP meeting with the appropriate representatives present. 229

In finding the private school had liability under the IDEA, the court concentrated on the New Jersey regulations implementing the IDEA. ${ }^{230}$

As a private school accepting placements of students protected by the IDEA, Windsor is subject to IDEA regulations, and it can therefore be held liable under the IDEA for its failure to comply with IDEA rules in connection with the termination of J.N.'s placement. New Jersey regulations implementing the IDEA are expressly made applicable to private entities providing publicly funded educational programs and services to students with disabilities. . . . Accordingly, if the state regulations reach a private school in Windsor's position, which they appear to do, then Windsor is subject to liability for violations of the IDEA. ${ }^{231}$

The court differentiated St. Johnsbury by noting that the implementing regulations in Vermont restricted due process hearings to actions against public agencies. ${ }^{232}$ The court noted that the New Jersey regulation contained no such restriction. ${ }^{233}$

However, the court went further than simply considering the implementing regulations, and reasoned that the private school might be nonetheless liable under the IDEA merely by taking publically placed students. ${ }^{234}$

In addition, it appears that St. Johnsbury may have inferred too much from the (entirely sound) proposition that public educational authorities cannot divest themselves of their responsibilities under the IDEA by placing children with disabilities in private schools. The fact that, even in the case of private school placement, "responsibility for compliance with IDEA remains with the public agency," ... does not imply that the no responsibility falls upon the private school: it is not by any means illogical for both the public authority (which has the initial and ultimate obligation to educate the child) and the private school (which is actually entrusted with the task and given the requisite funds) to be subject to IDEA rules. ${ }^{235}$

Thus, like so many other aspects of the IDEA, the courts offer no clear resolution to the question.

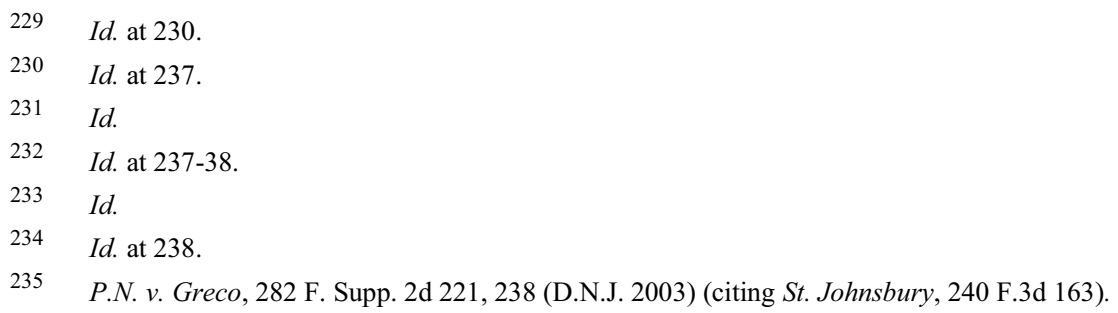




\section{The Need for Clarity}

The drafters' failure to specify whether this provision applies to private schools demonstrates the ongoing need to clarify and, in some cases, redraft portions of the IDEA. There is urgent need for action, either by Congress, by amending the IDEA, the Supreme Court, by taking up the case, or by the Department of Education, by issuing clarity in the Code of Federal Regulations.

Not only private schools experience hardship as a result of this uncertainty, but students and educators as well. Education services, along with safety and stability, are at risk. The combination of endless proceedings while a stay put placement is in force, and the uncertainty about whether private schools are even subject to the provision, create some of the very problems the IDEA was designed to remedy.

States may help by clarifying in their own state regulations whether the stay put mandate applies to private schools. However, states accepting federal funding may not offer less protection to students than those assured by the IDEA. Any state action would essentially be a stop-gap measure. Cases will continue to come until there is some action, either by Congress, the Department of Education, or the Supreme Court. Although the students affected may appear small, the risks are quite large. There are good arguments on either side of this issue, but no good argument for leaving the matter in limbo.

\section{CONCLUSION}

In many ways, the IDEA has accomplished what it set it out to do. Children who would otherwise have gone without any education now have access to appropriate education services. These students have gained the ability to live more productive, fulfilling lives.

As the education landscape evolves, the ability for specialized private schools to offer meaningful, appropriate education to students who would otherwise be without services is, in many ways, revolutionary. These students are often now able to be educated with their peers and enjoy an education that is geared specifically toward them. Parents can rely upon the expertise of professionals trained to work with increasingly specific populations with specific needs. In this way the IDEA has allowed whole populations of students to benefit from educational services they would otherwise be denied. The benefits of the IDEA cannot be overstated.

Yet ongoing issues with the IDEA demonstrate the urgent need for resolution of these issues. With a statute as far reaching as the IDEA, guidance is necessary for the correct application of the statute. The stay put provision offers certainty and stability to students, guaranteeing their access to continuing and, hopefully, appropriate services pending the resolution of these disputes. Yet the current application of the IDEA threatens to harm the very students it was designed to help. Education is at risk - clarity and action are needed. 